\title{
Palaeodietary and Palaeoclimatic Reconstruction for Late Miocene Hipparionines from the Siwaliks of Pakistan
}

\author{
Muhammad Tahir Waseem ${ }^{1}$, Abdul Majid Khan ${ }^{1 *}$, Abdul Ghaffar ${ }^{2}$, Ayesha Iqbal ${ }^{1}$ \\ and Rana Manzoor Ahmad ${ }^{1,3}$ \\ ${ }^{1}$ Department of Zoology, University of the Punjab, Lahore, Pakistan. \\ ${ }^{2}$ Department of Zoology, Cholistan University of Veterinary and Animal Sciences, \\ Bahawalpur, Pakistan \\ ${ }^{3}$ Department of Zoology, University of Okara, Okara, Pakistan.
}

\begin{abstract}
A B S T R A C T
Dental materials of three hipparionine species from Dhok Pathan Formation (late Miocene) has been utilized in this study to reconstruct the palaeodiet and palaeoecology by using stable isotope analyses of carbon and oxygen of tooth enamel carbonate. A gradual increase in hypsodonty and complexity in plications indicate the drier environments with hard and tough food available during the late Miocene. The late Miocene hipparionines were expected to have inhabited a mosaic of woodland and grassland with predominant $\mathrm{C}_{3}$ vegetation which latter shifted to $\mathrm{C}_{3} / \mathrm{C}_{4}$ grasses. For this purpose, fifteen dental samples (Five for each Hipparion species) from well dated late Miocene localities between 8.8-7.7 Ma are analyzed. All the $\delta^{13} \mathrm{C}$ values (V-PDB) are in range of $-11.27 \%$ o to $-3.36 \%$ which represent that these horses dominantly inhabited $\mathrm{C}_{3}$ vegetation however, the $\mathrm{C}_{4}$ grasses were being indicated as the diet of Hipparionines the latest Miocene. All these species are believed to inhabit more open environment with patchy grasslands. Non-significant differences were observed between the species which explains that the dietary niche of these species was more or less similar. However, the values for carbon isotopes are highly depleted for early hipparionine species (Sivalhippus theobaldi) and less depleted for succeeding species (Sivalhippus perimensis and Cremohipparion antilopinum) which represent dominancy of $\mathrm{C}_{4}$ diet in more open habitat in later species. The values for $\delta^{18} \mathrm{O}$ are also not significantly different between these species indicating that water intake behavior was also, more or less, same for these species. $\delta^{18} \mathrm{O}$ (range between $-11.4 \%$ to $-3.8 \%$ ) variability may indicate a climatic shift in precipitation source or amount rainfall through time. We suspect that grasslands expanded at the expense of forests towards the latest Miocene while environment became drier and warmer. These analyses also reveal that hipparionines shifted from $\mathrm{C}_{3}$ browsing to mixed $\mathrm{C}_{3} / \mathrm{C}_{4}$ and to $\mathrm{C}_{4}$ diet at the end of Miocene.
\end{abstract}

\begin{tabular}{l} 
Article Information \\
Received 14 March 2018 \\
Revised 15 April 2019 \\
Accepted 21 October 2019 \\
Available online 27 March 2021 \\
Authors' Contribution \\
\hline MTW has helped in preparation and \\
interpretation of results. Samples have \\
also been prepared by him. AMK \\
helped in preparation of manuscript. \\
AG helped in samples analysis, \\
manuscript writing and practical \\
information about Hipparion. AI \\
identified Hipparion species. RMA \\
statistically analysed the data. \\
Key words \\
\hline Palaeodiet, C $/ C_{4}$ vegetation, Faunal \\
turnover, Palaeoclimate, Hipparions
\end{tabular}

Article Information

Accepted 21 October 2019

Available online 27 March 202

Authors' Contribution

interpretatiof in preparation and also been prepared by him. AMK helped in preparation of manuscript. AG helped in samples analysis, manuscript writing and practical information about Hipparion. AI identified Hipparion species. RM

Key words turnover, Palaeoclimate, Hipparions

\section{INTRODUCTION}

A 11 three toed horses, present in Mio-Pliocene are categorized under a unanimous term: hipparionines. In this time span hipparionine horses were wide spread across the Old as well as New World (Colbert, 1935; Webb, 1969). Due to the ubiquitous nature of all these horses across the Old World, particularly, they are often termed as "Hipparion Fauna" and it is more related to Neogene time span. The description of Neogene horses is chiefly based on their dental character and also on the basis of post cranial features, but to a lesser extent (MacFadden, 1984).

Hipparionines are widely distributed in the Middle Siwaliks of Pakistan, most specifically during the late Miocene to Pliocene time span (MacFadden and Bakr, 1979;

\footnotetext{
* Corresponding author: majid.zool@pu.edu.pk 0030-9923/2021/0003-1035\$9.00/0

Copyright 2021 Zoological Society of Pakistan
}

Bernor and Hussain, 1985; Ghaffar, 2005; Wolf et al., 2013). The enamel pattern of these hipparionine species is relatively complicated as compared to living genera of horses. The complexity in dental structures of extinct hipparionine species indicates an addition of tougher food along the temporal boundaries of late Miocene. According to Wolf et al. (2013) different species of this group reported from the Siwaliks are Sivalhippus nagriensis, Sivalhippus theobaldi, Sivalhippus perimensis, Sivalhippus anwari, Cremohipparion antilopinum and Cremohipparion sp.

One of the most significant event of latest Miocene is the expansion of $\mathrm{C}_{4}$ grasslands and the reasons behind this global phenomenon is the uplifting of Himalayan mountain belt, decrease in atmospheric $\mathrm{CO}_{2}$ levels and warmer conditions. This decrease in annual rainfall patterns is interpreted from the $\delta^{18} \mathrm{O}$ values of equid teeth (Nelson, 2005). According to literature review (i-e., Cerling et al., 1989; Barry et al., 2002; Nelson, 2005, 2007; Badgley et al., 2008; Damingo et al., 2009) late Miocene record at ca. 
8.5 Ma represent a transition from wet monsoon forest to dry monsoon forest at ca. $7 \mathrm{Ma}$ to savannah at ca. $6 \mathrm{Ma}$. Cerling et al. (1993) have investigated the paleosols and tooth enamel from various localities of Pakistan and North America and reported that $\mathrm{C}_{4}$ expansion happened at ca.7 $\mathrm{Ma}-5 \mathrm{Ma}$ and according to authors, this expansion was the result of decrease in atmospheric concentration of $\mathrm{CO}_{2}$ while Pagani et al. (1999) associated the $\mathrm{C}_{4}$ expansion with increasing episodes of low latitude aridity and seasonal precipitation pattern on global scale.

The present study is an attempt to investigate the palaeoclimate and palaeodiet of three late Miocene hipparionine species by using the stable isotope analysis of carbon and oxygen. As it is known that hipparionine horses were widely distributed in Middle Siwaliks of Pakistan, which spans the late Miocene-Pliocene time period, so this study will help to understand the changes in environment and dietary patterns as well as to co-relate it with previous studies which were based on morphological and morphometric interpretations from the Siwaliks (Ghaffar, 2005; Ghaffar et al., 2004; Wolf et al., 2013) as well as stable isotope data (Cerling et al., 1989; Nelson, 2005, 2007; Bibi, 2007).

Stable isotopic data for oxygen is associated to body water, which corresponds the water uptake behaviors of animals (Byrant and Froelich, 1995). The oxygen values explain weather the animal was an obligate drinker/ passive drinker or taken his water from open evaporating water holes/shaded ponds/riverine water (Kohn, 1996). While considering the evaporative enrichment factor, the leaf water values of plants are being recorded 10-30\%o more positive than meteoric water which allows us to test the hypothesis that whether hipparionines were dependent on their food or on water holes for their water intake (Yakir, 1997; Sponheimer and Lee-Thorp, 2001). On the other hand, carbon isotope values explore the dietary composition ingested by the animals (Quade et al., 1992). Both these isotopic values together are quite helpful in understanding of dietary and climatic structure as well as water intake behavior.

Along the tropics and sub tropics (the Siwaliks system), $\mathrm{C}_{4}$ pathway of photosynthesis is dominantly present in grasses which make such flora enable to thrive in heat stressed and seasonally arid conditions (Tipple and Pegani, 2007). The record of stable isotope studies indicate that $\mathrm{C}_{4}$ vegetation did not expand in the Siwaliks promptly but gradually (Quade and Cerling, 1995). The emergence of $\mathrm{C}_{4}$ vegetation in the Siwalik is estimated to be around 8.1 Ma. However, the first dominated habitats which were more exposed to faunal elements appeared at about 7.4 Ma (Quade et al., 1989; Barry et al., 2002). Now all these facts suggest that early hipparionine species must be feeding in an open $\mathrm{C}_{3}$ environment, $\mathrm{C}_{3}$ grasslands more appropriately. Stable isotope analysis plays a vital role here as it can readily differentiate the $\mathrm{C}_{3}$ vegetation from $\mathrm{C}_{4}$ provided that $\mathrm{C}_{3}$ flora represents $\delta^{13} \mathrm{C}$ values in range of $-35 \%$ to $-22 \%$ while $\mathrm{C}_{4}$ vegetation lies in the range of $-19 \%$ to $-9 \%$ as described by Bender (1971). But there are a number of factors which affect this ratio and alter it, these factors include alteration in partial pressure as well as ${ }^{13} \mathrm{C} /{ }^{12} \mathrm{C}$ ratios of atmospheric carbon dioxide (Passey et al., 2002). It was estimated by Cerling and Harris (1999) that with respect to the plant source, the bioapetite of large animals (e.g. horses) shows an enrichment of about $+14.1 \pm 0.5 \%$. After the estimation of all enrichment factors, Cerling and Harris (1999) reported that values range from - $16 \%$ to $-9 \%$ in the case of $\mathrm{C}_{3}$ vegetation, while $\mathrm{C}_{4}$ vegetation shows the $\delta^{13} \mathrm{C}$ values between $-2 \%$ to $+3 \%$ o for tooth enamel. The depleted values of $\delta^{13} \mathrm{C}$ indicate a closed habitat (Forest land ecology) while enriched values indicate more open habitat (most likely woodlands and grasslands) (Nelson, 2005).

In our study, we used enamel rather than bone because enamel is resilient to diagenetic effects which can alter isotopic values in fossils (Lee Throp and Sponheimer, 2003). There are many reasons of using mammalian fossils over paleosols like straightforward identification and isotopic signals are enhanced in mammals due to selective feeding as reported by Cerling et al. (1997).

In this study, stable carbon and oxygen isotopic analyses have been done for fifteen samples of hipparions from Dhok Pathan Formation (Fig. 1) of the Siwaliks of Pakistan ranging from late Miocene to latest Miocene.

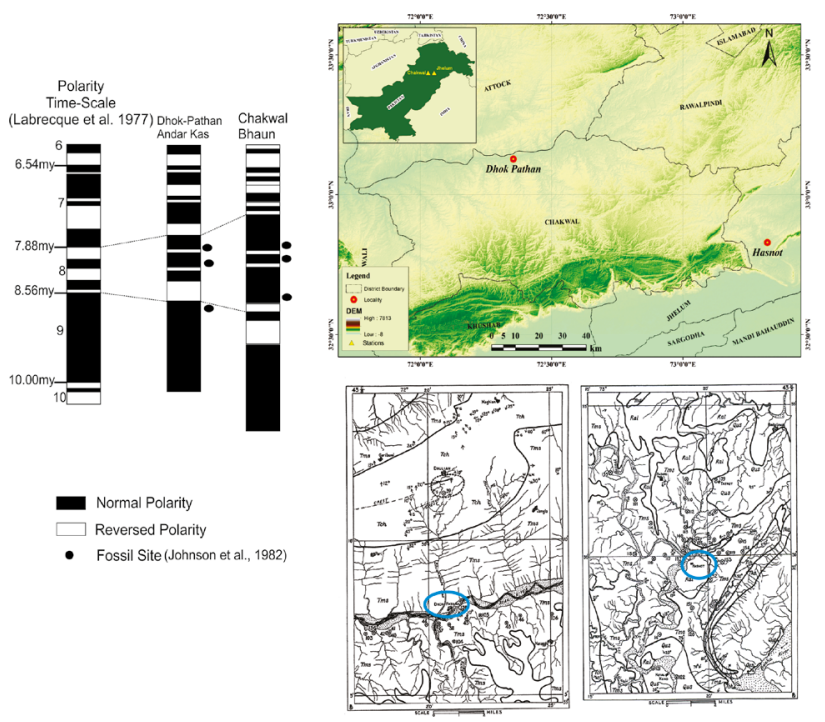

Fig. 1. The studied sites along with the localities. 


\section{MATERIALS AND METHODS}

\section{Sampling}

Tooth enamel samples of three species of hiparionines, five samples from each species, Sivalhippus cf. theobaldi, Sivalhippus cf. perimensis, and Cremohipparion cf. antilopinum from the Siwalik of Pakistan were analyzed for the estimation of carbon and oxygen ratios in tooth enamel. Samples were collected from the Dhok Pathan Formation (late Miocene) of the Siwaliks. All the samples are preserved at Palaeontology and Environmental Biology Lab, Department of Zoology, University of the Punjab, Lahore, Pakistan. An excellent collection ( $\sim 500$ samples) of hipparionine horses having maxillae and mandibles in addition to upper and lower incisors, canines, premolars and molars has been housed at this university. Among this collection precisely identified specimens of Sivalhippus theobaldi, Sivalhippus perimensis, and Cremohipparion antilopinum were picked for isotopic analyses because in our collection very few specimens belong to Sivalhippus nagriensis. The fossil collection of specimens under study along with their respective ages has been given in Table I.

\section{Enamel extraction}

To obtain a drilled sample of tooth enamel, samples first washed, dried and scrubbed with wire brush to remove adhesive dust or contamination. The samples were then drilled by M-3 Champion drill machine to get the enamel extract in powder form. Drilling was done from root to crown direction from the lingual side of the tooth in a closed chamber (Fig. 1). The powder was collected and transferred to plastic vials by using a fine tipped brush. Each vial contains $15 \mathrm{mg}$ of drilled enamel powder. For the analyses of enamel extract the samples were subjected to the Isotope Ratio Mass Spectrometer in PINSTECH (Pakistan Institute of Nuclear Science and Technology) Islamabad. Statistical analysis was done by using SPSS (Statistical Package for the Social Sciences) 16.0 version. Normality test was applied to check weather our data is normally distributed or not and then ANOVA (Analysis of Variance) test was applied with Duncan test for further results.

\section{Pre-treatment and analysis of samples}

The powdered sample of enamel was treated with $\mathrm{H}_{2} \mathrm{O}_{2}$ and $\mathrm{CH}_{3} \mathrm{COOH}$ to counter the effects of inorganic and organic contaminants as proposed by Koch et al. (1997). Then enamel was further treated with $30 \% \mathrm{H}_{2} \mathrm{O}_{2}$ for overnight, washed with de-ionized $\mathrm{H}_{2} \mathrm{O}$, reacted with $0.1 \mathrm{~N} \mathrm{CH}_{3} \mathrm{COOH}$ for $4 \mathrm{~h}$ and samples were washed. Ethanol was added and samples were left for drying out for $24 \mathrm{~h}$. For $\mathrm{CO}_{2}$ production, the enamel samples were dissolved in $95 \% \mathrm{H}_{3} \mathrm{PO}_{4}$. The $\mathrm{CO}_{2}$ was analyzed with an IRMS (Isotope Ratio Mass Spectrometry) at PINSTECH, Islamabad.

One solid carbonate $\left(\mathrm{CaCO}_{3}\right)$ and two gaseous $\left(\mathrm{CO}_{2}\right)$ standards were prepared and calibrated against V-PDB for internal use. The reproducibility of results and accuracy of mass spectrometric analysis was within the internationally accepted limits of $0.1-0.2 \%$.

Mass spectrometric analysis of $\mathrm{CO}_{2}$ is performed through isotopic masses ${ }^{12} \mathrm{C}^{16} \mathrm{O}^{16} \mathrm{O},{ }^{13} \mathrm{C}^{16} \mathrm{O}^{16} \mathrm{O},{ }^{12} \mathrm{C}^{16} \mathrm{O}^{16} \mathrm{O}$, ${ }^{12} \mathrm{C}^{16} \mathrm{O}^{18} \mathrm{O},{ }^{13} \mathrm{C}^{16} \mathrm{O}{ }^{17} \mathrm{O},{ }^{12} \mathrm{C}^{17} \mathrm{O}^{17} \mathrm{O},{ }^{12} \mathrm{C}^{16} \mathrm{O}^{17} \mathrm{O}$. For carbon- 13 analysis, we measured mass 45 versus combined mass 44 + mass 45 in $\mathrm{CO}_{2}$. Similarly, for the analysis of oxygen, we measured mass 46 versus the combined mass $44+$ mass 45 in $\mathrm{CO}_{2}$.

Table I. The stable isotope values of carbon and oxygen along with the localities and age information.

\begin{tabular}{llllll}
\hline $\begin{array}{l}\text { Sample } \\
\text { code. }\end{array}$ & $\begin{array}{l}\text { PUPC } \\
\text { No. }\end{array}$ & $\begin{array}{l}\text { Local- } \\
\text { ities }\end{array}$ & $\begin{array}{l}\text { Ages (Ma) (John- } \\
\text { son } \text { et } \text { al., 1982) }\end{array}$ & $\begin{array}{l}\boldsymbol{\delta}^{13} \text { Cc \% } \\
\text { (V-PDB) }\end{array}$ & $\begin{array}{l}\boldsymbol{\delta}^{18} \text { Oc \%o } \\
\text { (V-PDB) }\end{array}$ \\
\hline EB-01 & $83 / 80$ & DP 3 & 7.7 & -5.10 & -7.12 \\
EB-202 & $85 / 53$ & DP 3 & 7.7 & -3.36 & -7.14 \\
EB-203 & $86 / 153$ & DP 2 & 7.7 & -4.94 & -3.81 \\
EB-102 & $00 / 24$ & DP 4 & 8.0 & -6.83 & -8.40 \\
EB-103 & $08 / 718$ & DP 4 & 8.0 & -6.67 & -7.71 \\
EB-101 & $67 / 339$ & DP 4 & 8.3 & -7.27 & -8.98 \\
EB-105 & $86 / 98$ & DP 4 & 8.3 & -7.75 & -9.21 \\
EB-204 & $02 / 119$ & DP 4 & 8.3 & -7.93 & -9.57 \\
EB-205 & $08 / 568$ & DP 4 & 8.3 & -8.80 & -8.18 \\
EB-02 & $94 / 66$ & DP 4 & 8.3 & -8.50 & -8.01 \\
EB-03 & $11 / 15$ & DP 4 & 8.3 & -7.92 & -11.03 \\
EB-205 & $08 / 568$ & DP 4 & 8.3 & -8.80 & -8.18 \\
EB-05 & $06 / 15$ & DP 5 & 8.4 & -9.50 & -11.48 \\
EB-104 & $83 / 317$ & DP 6 & 8.4 & -9.94 & -9.90 \\
EB-201 & $68 / 720$ & DP 5 & 8.4 & -9.45 & -6.89 \\
EB-04 & $83 / 802$ & DP 5 & 8.8 & -11.27 & -10.38 \\
\hline
\end{tabular}

For the ages of the specimens, the sections of Johnson et al. (1982) are correlated with geo-magnetic polarity time scale of LaBreque et al. (1977).

\section{RESULTS}

\section{Carbon isotope ratios}

Variations between all the hipparionine samples was found to be $8 \%$, ranging from $-11.27 \%$ to -3.36 . The mean values for Sivalhippus cf. theobaldi, Sivalhippus cf. perimensis and Cremohipparion cf. antilopinum is 
$-8.458 \%$, $-7.692 \%$ and $-6.896 \%$ respectively. Normality test indicates that all the values are normally distributed. The two-way ANOVA was performed along with Duncan test which indicated that the differences between these three species are not significant. Most of the values are carbon depleted while one value of Cremohipparion cf. antilopinum shows a value of $-3.36 \%$.

\section{Oxygen isotope ratio}

The $\delta^{18} \mathrm{O}$ values for all the samples range between $-11.48 \%$ to $-3.8 \%$. Means for $S$. cf theobaldi, $S$. cf. perimensis and Cremohipparion cf. antilopinum are $-9.604 \%$, $-8.84 \%$ and $-7.118 \%$, respectively. Shapiro Wilk test revealed that all the $\delta^{18} \mathrm{O}$ values are normally distributed $(\mathrm{P}>0.05)$. ANOVA indicated that difference between these species is not significant $(p=0.106)$.

Table I shows the stable isotope values of carbon and oxygen along with the localities and age information. For the ages of the specimens, the sections of Johnson et al. (1982) are correlated with geo-magnetic polarity time scale of LaBreque et al. (1979).

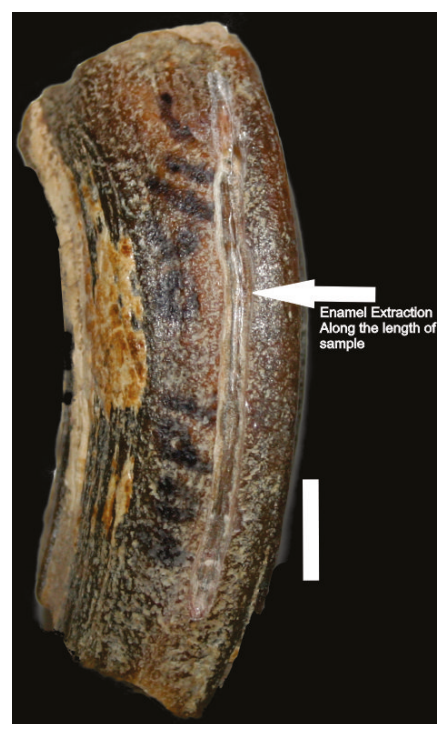

Fig. 2. Extraction of enamel from the Hipparion molar along the vertical axis. Scale bar indicates $10 \mathrm{~mm}$.

\section{DISCUSSION}

\section{Palaeodiets}

Generally, carbon isotope values (Table I, Fig. 3) follow the palaeodietary investigations based on the dental morphology. Most of the values of $\delta^{13} \mathrm{C}$ were depleted while one sample of Cremohipparion antilopinum was relatively enriched in $\delta^{13} \mathrm{C}$ value $(-3.76 \%)$. Carbon isotope values were however, not significantly different, but revealed fine variations between dietary behavior of these species. Sivalhippus theobaldi represent the most depleted values for carbon isotopes averaging $-8.4 \%$ as compared to Sivalhippus perimensis which shows an average value of $-7.6 \%$. Cremohipparion antilopinum is most enriched in carbon isotope values averaging $-6.8 \%$ (Fig. 3 ). These minor variations in mean values of respective species indicate insignificant change in feeding niche which can be explained on the basis of niche breadth over time. The dietary behavior changed from exclusive feeding on $\mathrm{C}_{3}$ grasses to a mixture of $\mathrm{C}_{3} / \mathrm{C}_{4}$ vegetation as it is indicated by dental morphological studies. More negative values for earlier species ( $S$. theobaldi) indicate a less tougher food compared to succeeding species i.e. $S$. perimensis and $C$. antilopinum. Rather than niche shift, it was increase in niche breadth represented by these species. $\mathrm{C}_{4}$ vegetation appeared in the Siwaliks around $\sim 7.4 \mathrm{Ma}$ as reported by Barry et al. (2002). Before this time period, there was dominant $\mathrm{C}_{3}$ vegetation on which these species relied. The present study strongly supports the hypothesis that early hipparions inhabited $\mathrm{C}_{3}$ vegetation while latter species experienced a mixture of $\mathrm{C}_{3} / \mathrm{C}_{4}$ vegetation with woodlands and patchy grasslands.

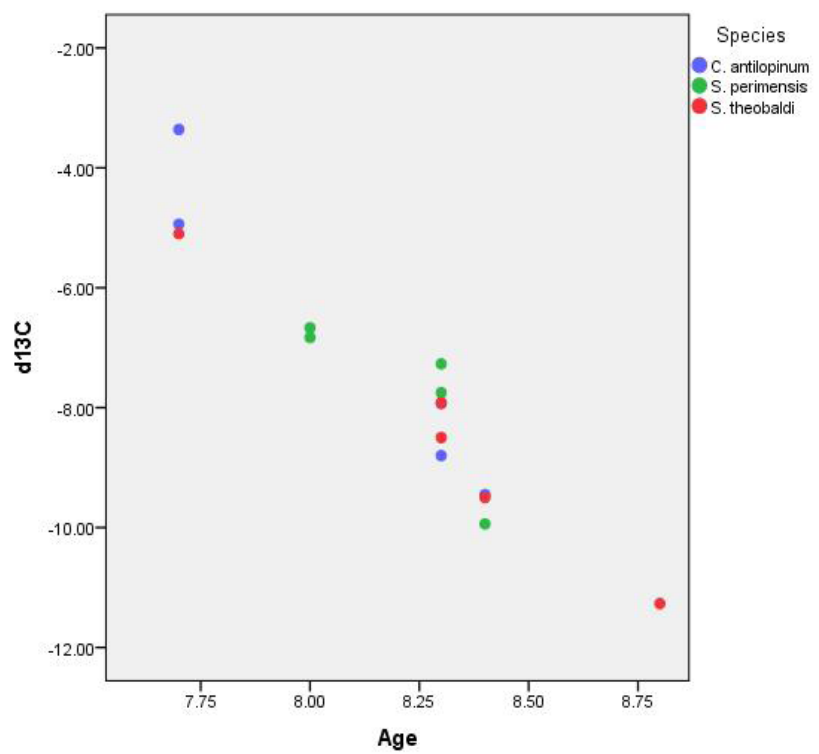

Fig. 3. The stable isotope of carbon along the age of the samples.

During late Miocene, a change in environment occurred globally, resulting into $\mathrm{C}_{4}$ expansion. The $\mathrm{C}_{4}$ expansion mainly depends upon temperature and partial pressure of atmospheric carbon dioxide as reported by Ehleringer and Monson (1993). Expansion of $\mathrm{C}_{4}$ is 
characterized by the higher temperatures, aridity and low $p \mathrm{CO}_{2}$ as $\mathrm{C}_{4}$ plants show the anatomical characters to reduce the loss of $\mathrm{CO}_{2}$ from leaf. Emergence of $\mathrm{C}_{4}$ ecosystem first appeared in low latitudes and was reported from paleosols studies of sediments from the Siwaliks of Pakistan by Morgan et al. (1994). Initial hypothesis for this change was made by Cerling et al. (1993) as he proposed this change was a consequence of global reduction in $p \mathrm{CO}_{2}$. In our study which spans from $8.8 \mathrm{Ma}$ to $7.7 \mathrm{Ma}$, a trend of positive isotope shift has been noted which, in turn, reveals the increase in $\mathrm{C}_{4}$ consumption in late Miocene by these hipparion species.

\section{Palaeoclimate}

The creation of more open habitats and decrease in close canopy forests and woodlands which resulted due to environmental change, exerted a pressure on inhabiting fauna and trend shifted from browsing/grazing on $\mathrm{C}_{3}$ vegetation to $\mathrm{C}_{4}$ grasses (Cerling et al., 1993; Nelson, 2005; Bibi, 2007). As reported by Barry et al. (2002), late Miocene was a period of great faunal and floral change, however, this study notices a fine niche expanded by the hipparion fauna due to this changing climate which represents that about $10.7 \mathrm{Ma}$, the degree of faunal change was not as rapid as afterwards. The depleted values of carbon $(-11.27 \%$ ) at $8.7 \mathrm{Ma}$ indicate forestland/woodland setting with humid conditions $\left(\delta^{18} \mathrm{O}=-10.38 \%\right)$. The environment became warmer and drier with the passage of time as at $8.3 \mathrm{Ma}$ the forest lands were more constricted and open lands (woodlands/grasslands) expanded more $\left(\delta^{13} \mathrm{C}=-8 \%\right.$ ) while rainfall became more seasonal $\left(\delta^{18} \mathrm{O}=\right.$ $-9 \%$ ), may be due to uplift of Himalaya which happened in late Miocene (Quade et al., 1989). At 7.7 $\mathrm{Ma} \mathrm{C}_{4}$ vegetation was a part of the ecosystem and the climatic conditions were warm and drier while monsoon shifted the most of the annual rainfall to the summer months April-July (Nelson, 2005). The comparative data of East Africa with the Siwaliks reports that the equids adapted to $\mathrm{C}_{4}$ dominant environment more rapidly compared to the Siwaliks (Fig. 4). This hypothesis is in-line with the hypothesis developed by Cerling et al. (1993) that $\mathrm{C}_{4}$ expanded earlier in low latitude regions.

These isotope shifts and $\mathrm{C}_{4}$ expansion can be associated with other factors rather than decrease in $p \mathrm{CO}_{2}$ as described by the following authors. These factors include regional dynamics like higher aridity and change in precipitation rates (Fox and Koch, 2004). This increase in seasonality and aridity may be attributed to uplift of Himalaya and consequent tectonic changes (Quade et al., 1989; Wang et al., 2006). Now all these changes triggered the weathering of silicate rocks which ultimately resulted in fall of atmospheric $p \mathrm{CO}_{2}$ (Ehleringer and Monson,

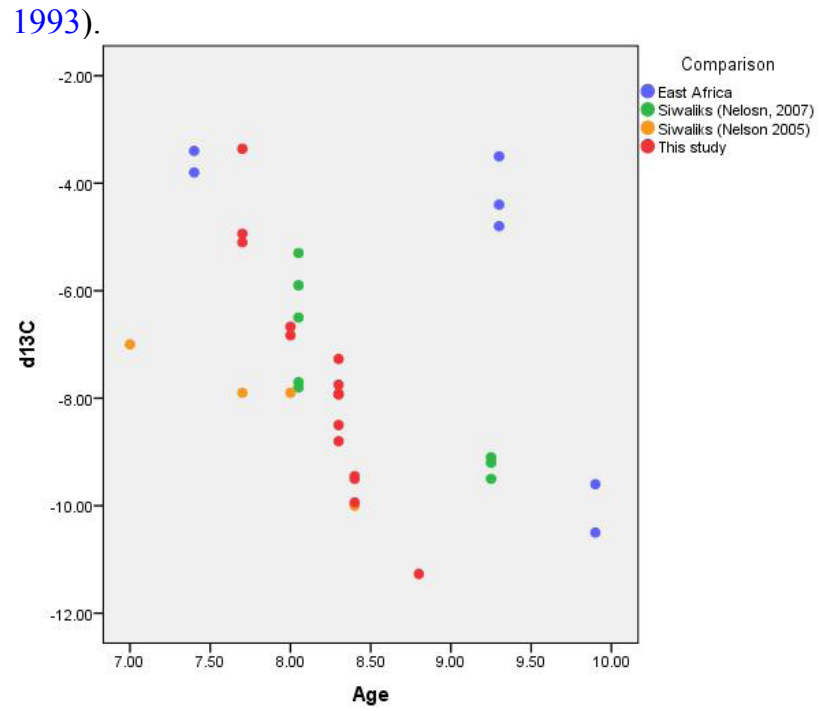

Fig. 4. A comparative picture of stable isotopes of carbon for the family Equidae across the late Miocene of the Siwaliks and East African habitats. Reference data taken from Nelson $(2005,2007)$ and Uno et al. (2011).

Cerling et al. (1993) reported the values of $\delta^{13} \mathrm{C}$ for equids indicating that before $8 \mathrm{Ma}$ the diet of these equids was dominantly $\mathrm{C}_{3}$ but after $8 \mathrm{Ma}$ the trend started to shift towards the $\mathrm{C}_{4}$ dietary niche. We attribute all above reported changes as the reason of faunal turnover and since animals were forced to expand their dietary niche they encountered a new habitat consisting of open grass and lands dominantly. The animals who survived this faunal turnover adapted to new habitats (Marino et al., 1991) while others became extinct or migrated. Less depleted values of carbon isotopes along the temporal gradient in late Miocene (from $11.27 \%$ o to $3.36 \%$ ) indicates a shift in vegetation pattern. Our study supports all these evidences and suggests that in late Miocene there was $\mathrm{C}_{4}$ expansion between 8-5 Ma.

\section{Oxygen isotope ratios}

The means of oxygen isotope ratio (Fig. 5) for these three species are not significantly different. The highly depleted values are reported for grazers by Sponheimer and Leethorp (1999). Mainly oxygen values depend upon many factors like feeding from canopy tops (enriched) in comparison to feeding from understories (depleted), which can be seen in Bovids (Bibi, 2007), water intake from evaporating water holes (enriched) in comparison to water intake from rivers (depleted).

These horses can be attributed as obligate drinkers from standing water which indicates that $S$. theobaldi relied on the shaded ponds for their water intake (average 
$\delta^{18} \mathrm{O}=-9.6 \%$ ) while the later species were taking water from more open evaporative water holes as indicated by higher oxygen isotope values (average $\delta^{18} \mathrm{O}=-7.9 \%$ ).

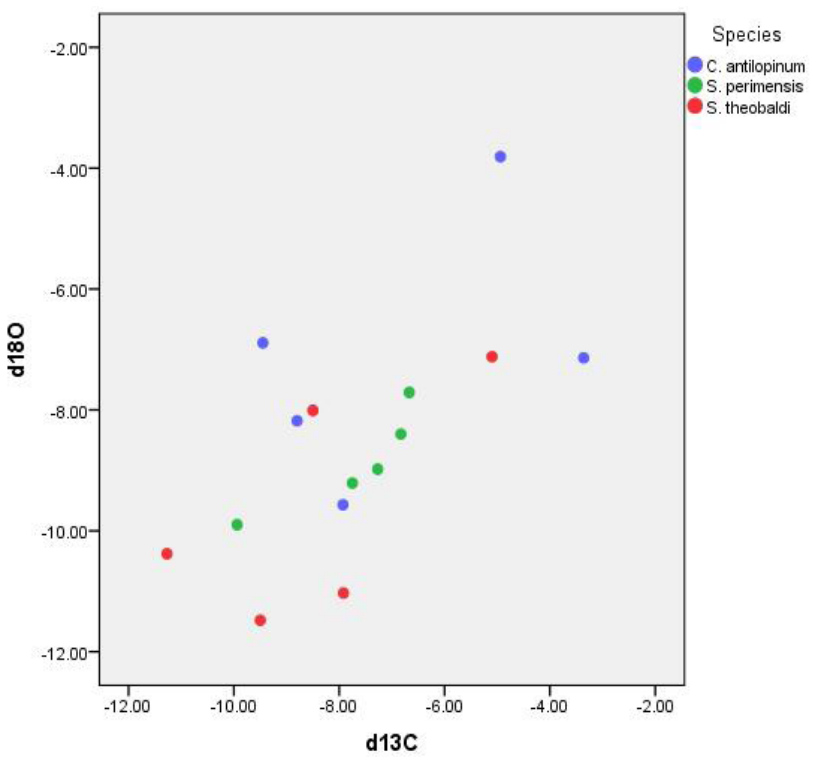

Fig. 5. Carbon and oxygen stable isotopic values for dental specimens of hiparionines.

On the basis of isotopic analysis of the fossils materials of hipparionine, we can argue;

(1) that the $\mathrm{C}_{3}$ vegetation was dominantly present in the Siwalik continental deposits till 8.8 Ma Ma and then there was shift toward $\mathrm{C}_{3} / \mathrm{C}_{4}$ vegetation $(8 \mathrm{Ma}$ ) or more dominantly $\mathrm{C}_{4}$ vegetation started $(7.7 \mathrm{Ma})$. So, we can conclude that till $\sim 10-5 \mathrm{Ma}$ both $\mathrm{C}_{3} / \mathrm{C}_{4}$ type of vegetation was present but for $\sim 10-7 \mathrm{Ma}$, more $\mathrm{C}_{3}$ and less $\mathrm{C}_{4}$ type of vegetation was present and after that $\sim 7-5 \mathrm{Ma}$ more $\mathrm{C}_{4}$ and less $\mathrm{C}_{3}$ type of vegetation was present. According to different authors (Cerling et al., 1997; Quade et al., 1994; 1995; Zachos et al., 2001) the monsoon season was much likely similar in the Dhok Pathan Formation as of present days in which both types of vegetation are present in the Siwaliks.

(2) Till date we do not have any material of Sivalhippus nagriensis from Nagri Formation, but we collected very few specimens from Dhok Pathan Formation as compared to other three species mentioned in this study (S. cf theobaldi, S. cf. perimensis and Cremohipparion cf. antilopinum).

(3) Based on dental morphology and paleoecology, we agree that $S$. theobaldi has less derived characters as compared to $S$. perimensis and the oldest occurrence of this species confirms the fact while the younger stratigraphic range of $S$. perimensis suggests that this species might be derived from $S$. nagriensis.

(4) Higher values of $\delta^{13} \mathrm{C}$ in one sample of Cremohipparion cf. antilopinum reveal that this species was present at the time of higher monsoon season while the hypsodonty index of $S$. theobaldi and $S$. perimensis suggest that these species relied more on $\mathrm{C}_{3} / \mathrm{C}_{4}$ and even more $\mathrm{C}_{4}$ type vegetation as compared to $\mathrm{C}_{3}$ vegetation.

(5) The gradual complexity in the teeth of hipparionines indicate that these species were trying to adapt with new vegetational type and were successful until $\mathrm{C}_{4}$ became very dominant hence Hipparions replaced by Equids by the Pliocene time span.

\section{CONCLUSION}

Fossil Hipparionine samples are subjected to stable isotopic analysis belonging to the late Miocene of Pakistan. The carbon isotope values suggested that the early hipparions were dominantly relied upon $\mathrm{C}_{3}$ vegetation while latter species consumed a mixture of $\mathrm{C}_{3} / \mathrm{C}_{4}$ grasslands for their diet. Our study follows the hypothesis developed on the basis of morphologic studies and also discriminates between open and closed environment in the late Miocene. However, this study also helps us to understand the palaeoclimatic conditions more deeply.

Values greater than $-9 \%$ are reported from our study indicate the emergence of $\mathrm{C}_{4}$ grasslands around $8 \mathrm{Ma}$ which may be attributed to low $p \mathrm{CO}_{2}$ and tectonic uplift of Himalaya. It is evident that not only single factor was involved in the late Miocene faunal turn over but a sequence of factors which may be responsible for the uplift of Himalaya, resulting the low $p \mathrm{CO}_{2}$ which in turn was responsible for the emergence of $\mathrm{C}_{4}$ grasslands. Our study also reports that in late Miocene the environment was warm and arid with open habitats. The variations between the isotopic values of these hipparionine species support the niche breadthening over niche shift during late Miocene in the Siwaliks.

\section{ACKNOWLEDGMENTS}

We warmly thank Dr. Sherry V. Nelson for her very useful comments and revisions on the early draft of the manuscript which helped us to improve the quality of the present work. We thank Prof. Dr. Jay Quade for his very useful comments on the methodology. The financial support for this work was provided by Higher Education Commission of Pakistan under Indigenous Scholarship awarded to $\mathrm{M}$. Tahir Waseem vide no. (17-5 (PhII)/2BS3-243/HEC/IS/2015). 
Statement of conflict of interest

The authors have declared no conflict of interest.

\section{REFERENCES}

Badgley, C., Barry, J.C., Morgan, M.E., Nelson, S.V., Behrensmeyer, A.K., Cerling, T.E. and Pilbeam, D., 2008. Ecological changes in Miocene mammalian record show impact of prolonged climatic forcing. Proc. natl. Acad. Sci. USA, 105: 12145-12149. https://doi.org/10.1073/pnas.0805592105

Barry, J.C. and Lindsay. 1982. A biostratigraphic zonation of the Middle and Upper Siwalik of the Potwar Plateau of northern Pakistan. Palaeogeogr. Palaeoclimatol. Palaeoecol., 37: 95-130. https:// doi.org/10.1016/0031-0182(82)90059-1

Barry, J.C., Morgan, M.E., Flynn, L.J., Pilbeam, D., Behrensmeyer, A.K., Raza, S.M., Khan, I.A., Badgley, C.,Hicks, J. and Kelley, J., 2002. Faunal and environmental change in the late Miocene Siwaliks of northern Pakistan. Paleobiology, 28: 1-71. https://doi.org/10.1666/00948373(2002)28[1:FAECIT]2.0.CO;2

Behrensmeyer, A.K., Quade, J., Cerling, T.E., Kappelman, J., Khan, I., Copeland, P., Roe, L., Hicks, J., Stubblefield, P., Willis, B. and LaTorre, C., 2007. The structure and rate of late Miocene expansion of $\mathrm{C} 4$ plants: Evidence from lateral variation in stable isotopes in paleosols of the Siwalik series, northern Pakistan. GSA Bull., 119: 1486-1505. https://doi.org/10.1130/B26064.1

Bender, M.M., 1971. Variations in the ${ }^{13} \mathrm{C} /{ }^{12} \mathrm{C}$ ratios of plants in relation to the pathway of photosynthetic carbon dioxide fixation. Phytochemistry, 10: 1239-1244. https://doi.org/10.1016/S00319422(00)84324-1

Bernor, R.L. and Hussain, S.T., 1985. An assessment of the systematic, phylogenetic and biogeographic relationships of Siwalik hipparionine horse. $J$. Verteb. Palaeontol., 5: 32-87. https://doi.org/10.10 80/02724634.1985.10011845

Bibi, F., 2007. Dietary niche partitioning among fossil bovids in late Miocene C3 habitats: Consilience of boundary. Palaeogeogr. Palaeoclimatol. Palaeoecol., 253: 529-538. https://doi. org/10.1016/j.palaeo.2007.06.014

Byrant, J.D. and Froelich, P.N., 1995. A model of oxygen isotope fractionation in body water of large mammals. Geochem. Cosmochism. Acta, 59: 4523-4537. https://doi.org/10.1016/00167037(95)00250-4
Cerling, T.E., Quade, J. and Wang, Y., 1994. Expansion and emergence of $\mathrm{C}_{4}$ plants. Nature, 371: 112. https://doi.org/10.1038/371112a0

Cerling, T.E., Quade, J., Wang, Y. and Bowman, J.R., 1989. Carbon isotopes in soils and paleosols as ecologic and paleoecologic indicators. Nature, 341: 138-139. https://doi.org/10.1038/341138a0

Cerling, T.E., Wang, Y. and Quade, J., 1993. Expansion of $\mathrm{C} 4$ ecosystems as an indicator of global ecological change in the late Miocene. Nature, 361: 344-345. https://doi.org/10.1038/361344a0

Cerling, T.E. and Harris, J.M., 1999. Carbon isotope fractionation between diet and bioapatite in ungulate mammals and implications for ecological and paleoecological studies. Oecologia, 120: 347363. https://doi.org/10.1007/s004420050868

Cerling, T.E., Harris, J.M., MacFadden, B.J., Leakey, M.G., Quade, J., Eisenmann, V. and Ehleringer, J.R., 1997b. Global vegetation change through the Miocene/Pliocene. Nature, 389: 153-158. https:// doi.org/10.1038/38229

Colbert, E.H., 1935. Siwalik mammals in the American Museum of Natural History. Trans. Am. Phil. Soc., N. S., 26: 1-401. https://doi.org/10.2307/1005467

Domingo, L., Cuevas-González, J., Grimes, S.T., Hernández Fernández, M. and López-Martínez, N., 2009. Multiproxy reconstruction of the paleoclimate and paleoenvironment of the Middle Miocene Somosaguas site (Madrid, Spain) using herbivore tooth enamel. Palaeogeogr. Palaeoclimatol. Palaeoecol., 272: 53-68. https://doi.org/10.1016/j. palaeo.2008.11.006

Ehleringer, J.R. and Monson, R.K., 1993. Evolutionary and ecological aspects of photosynthetic pathway variation. Annu. Rev. Ecol., 24: 411-439. https:// doi.org/10.1146/annurev.es.24.110193.002211

Fox, D.L. and Koch, P.L., 2004. Carbon and oxygen isotopic variability in Neogene paleosol carbonates: Constraints on the evolution of the C4grasslands of the Great Plains, USA. Palaeogeogr. Palaeoclimatol. Palaeoecol., 207: 305-329. https:// doi.org/10.1016/S0031-0182(04)00045-8

Ghaffar, A., Akhtar, M. and Khan, M.A., 2015. New fossil remains of family cervidae from the Dhok Pathan formation (Middle Siwaliks) of Pakistan. Geosci. J., 19: 631-639. https://doi.org/10.1007/ s12303-015-0001-X

Ghaffar, A., 2005. Studies on equids, cervids and carnivora from the Siwalik hills of Pakistan. Ph.D. thesis, University of the Punjab, Lahore, Pakistan.

Ghaffar, A., Khan, M.A., Nazir, M., 2004. Note on milk molars of Hipparion theobaldi. Sci. Int., 16: 291- 
293.

Ghaffar, A., Akhtar, M., Samiullah, K., Khan, A.M., Iqbal, M. and Khan, M.A., 2012. Discovery of antler from a new site in the Pinjor Formation (Pleistocene) of Pakistan. J. geol. Soc. India, 80: 119-122. https:// doi.org/10.1007/s12594-012-0125-9

Hill, A., 1995. Paleoclimate and Evolution with Emphasis on Human Origins (eds. E.S. Vrba, G.H. Denton, T.C. Partridge and L.H. Burckle) J. Quat. Sci., 14: 178-193.

Hussain, S.T., 1971. Revision of Hipparion (Equidae, Mammalia) from the Siwaliks Hills of Pakistan and India. Abh. Bayer. Akad. Wiss., Math-Naturwiss., 147: 1-168.

Johnson, N.M., Opdyke, N.D., Johnson, G.D., Linday, E.H. and Tahirkheli, R.A.K., 1982. Magnetic polarity stratigraphy and ages of the Siwalik Group Rocks of the Potwar Plateau, Pakistan. Palaeogeogr. Palaeoclimatol. Palaeoecol., 37: 17-42.

Kingston, J.D., Marino, B. and Hill, A., 1994. Isotopic evidence for Neogene hominid paleoenvironments in the Kenya Rift Valley. Science, 264: 955-959. https://doi.org/10.1126/science.264.5161.955

Koch, P.L., Tuross, N. and Fogel, M.L., 1997. The effects of sample treatment and diagenesis on the isotopic integrity of carbonate in biogenic hydroxylapatite. $J$. Archaeol. Sci., 24: 417-429. https://doi.org/10.1006/ jasc. 1996.0126

Kohn, M.J., 1996. Predicting animal 180: Accounting for diet and physiological adaptation. Geochim. Cosmochim. Acta, 60: 4811-4829. https://doi. org/10.1016/S0016-7037(96)00240-2

LaBrecque, J.L., Kent, D.V. and Cande, S.C., 1977. Revised magnetic polarity timescale for the late Cretaceous and Cenozoic time. Geology, 5: 330-335.

Lee-Thorp, J. and Sponheimer, M., 2003. Three case studies used to reassess the reliability of fossil bone and enamel isotope signals for paleodietary studies. J. Anthropol. Archaeol., 22: 208-216. https://doi. org/10.1016/S0278-4165(03)00035-7

Macfadden, B.J. and Bakr, A., 1979. The horse cremohipparion theobaldi from the neogene of Pakistan, with comments on Siwalik Hipparion. Palaeontology, 22: 439-447.

MacFadden, B.J., 1984. Systematics and phylogeny of Hipparion, Neohipparion, Nannippus, Cormohipparion (Mammalia, Equidae) from Miocene and Pliocene of New World. Bull. Am. Mus. nat. Hist., 179: 1-196.

Marino, B.D. and McElroy, M.B., 1991. Isotopic composition of atmospheric $\mathrm{CO}_{2}$ inferred from carbon in C4 plant cellulose. Nature, 349: 127-131. https://doi.org/10.1038/349127a0

Morgan, M.E., Kingston, J.D. and Marino, B.D., 1994. Carbon isotope evidence for the emergence of C4 plants in the Neogene from Pakistan and Kenya. Nature, 367: 162-165. https://doi. org/10.1038/367162a0

Nelson, S.V., 2005. Paleoseasonality inferred from equid teeth and intra-tooth isotopic variability. Palaeogeogr. Palaeoclimatol. Palaeoecol., 222: 122-144. https:// doi.org/10.1016/j.palaeo.2005.03.012

Nelson, S.V., 2007. Isotopic reconstructions of habitat change surrounding the extinction of Sivapithecus, a Miocene hominoid, in the Siwalik Group of Pakistan. Palaeogeogr. Palaeoclimatol.Palaeoecol., 243:204222. https://doi.org/10.1016/j.palaeo.2006.07.017

Passey, B.H., Robinson, T.F., Ayliffe, L.K., Cerling, T.E., Sponheimer, M., Dearing, M.D., Roeder, B.L. and Ehleringer, J.R., 2005. Carbon isotope fractionation between diet, breath $\mathrm{CO}_{2}$, and bioapatite in different mammals. J. Archaeol. Sci., 32: 1459-1470. https:// doi.org/10.1016/j.jas.2005.03.015

Pagani, M., Freeman, K.H. and Arthur, M.A., 1999. Late Miocene atmospheric $\mathrm{CO} 2$ concentrations and the expansion of C-4 grasses. Palaeogeogr. Palaeoclimatol. Palaeoecol., 253: 529-538. https:// doi.org/10.1126/science.285.5429.876

Quade,J., Cerling, T.E. andBowman J.R., 1995.Expansion of $\mathrm{C}_{4}$ grasses in the late Miocene of northern Pakistan: Evidence from stable isotopes in paleosols. Palaeogeogr. Palaeoclimatol. Palaeoecol., 115: 91116. https://doi.org/10.1016/0031-0182(94)00108-K

Quade, J., Cerling, T.E., Barry, J.C., Morgan, M.E., Pilbeam, D.R., Chivas, A.R., Lee-Throp, J.A., Nikolaas, J. and van der Merwe, 1992. A 16-Ma record of paleodiet using carbon and oxygen isotopes in fossil teeth from Pakistan. Chem. Geol., 94: 183192. https://doi.org/10.1016/S0009-2541(10)800038

Quade, J., Cerling, T.E., Andrews, P. and Alpagut, B., 1995. Paleodietary reconstruction of Miocene faunas from Pasalar, Turkey using stable carbon and oxygen isotopes of fossil tooth enamel. J. Human Evolut., 28: 373-384. https://doi.org/10.1006/jhev.1995.1029

Quade, J. and Cerling, T.E., 1995. Expansion of C4 grasses in the Late Miocene of Northern Pakistan: evidence from stable isotopes in paleosols. Palaeogeogr. Palaeoclimatol. Palaeoecol., 115: 91-116.

Quade, J., Solounias, N. and Cerling, T.E., 1994. Stable isotopic evidence from paleosol carbonates and fossil teeth in Greece for C3 forest or woodlands over the past 11 Ma. Palaeogeogr. Palaeoclim. Palaeoecol., 108: 41-53. https://doi.org/10.1016/0031- 
0182(94)90021-3

Sponheimer, M. and Lee-Thorp, J.A., 1999. Oxygen isotopes in enamel carbonate and their ecological significance. J. Archaeol. Sci., 26: 723-728. https:// doi.org/10.1006/jasc.1998.0388

Tipple, B. and Pagani, M., 2007. The early origins of terrestrial C4 photosynthesis. Annu. Rev. Earth Planet Sci., 35: 435-461. https://doi.org/10.1146/ annurev.earth.35.031306.140150

Uno, K.T., Cerling, T.E., Harris, J.M., Kunimatsu, Y., Leakey, M.G., Nakatsukasa, M. and Nakaya, H., 2011. Late Miocene to Pliocene carbon isotope record of differential diet change among East African Herbivores. Proc. natl. Acad. Sci., 108: 6509-6514.

Wang, Z., Calderon, M.M. and Carandang, M.G., 2006. Effects of resin tapping on optimal rotation age of pine secondary forest. J. For. Econ., 11: 245260. https://doi.org/10.1016/j.jfe.2005.10.001
Webb, S.D., 1969. The Burge and Minnechaduza Clarendonian Mammalian Faunas of North-Central Nebraska. Univ. Calif. Public Geol. Sci., 78: 1-191.

Wolf, D., Bernor, R.L. and Hussain, S.T., 2013. A systematic, biostratigraphic, and paleobiogeographic reevaluation of the Siwalik Hipparionine horse assemblage from the Potwar Plateau, Northern Pakistan. Palaeontogr. Abt. A., 300: 1-11. https:// doi.org/10.1127/pala/300/2013/1

Yakir, D., 1997. Oxygen-18 of leaf water: a crossroad for plant associated isotopic signals. In: Stable isotopes: Integration of biological, ecological, and geochemical processes (ed. H. Griffiths). BIOS, Oxford, pp. 147-168.

Zachos, J., Pagani, M., Sloan, L., Tomas, E. and Billups, K., 2001. Trends, rhythms, and aberrations in global climate 65 Ma to present. Science, 292: 5517. https:// doi.org/10.1126/science.1059412 